\title{
"Effect of strategic management accounting techniques on market share changes in firms in Tehran Stock Exchange market"
}

\begin{tabular}{ll} 
AUTHORS & $\begin{array}{l}\text { Behjat Abbasi } \\
\text { Mohammad Hamed Khan Mohammadi }\end{array}$ \\
\hline ARTICLE INFO & $\begin{array}{l}\text { Behjat Abbasi and Mohammad Hamed Khan Mohammadi (2016). Effect of } \\
\text { strategic management accounting techniques on market share changes in firms } \\
\text { in Tehran Stock Exchange market. Problems and Perspectives in Management, } \\
\text { 14(3-si), 325-331. doi:10.21511/ppm.14(3-si).2016.04 }\end{array}$ \\
\hline DOI & http://dx.doi.org/10.21511/ppm.14(3-si).2016.04 \\
\hline RELEASED ON & Thursday, 15 September 2016 \\
\hline JOURNAL & "Problems and Perspectives in Management" \\
\hline FOUNDER & LLC "Consulting Publishing Company "Business Perspectives"
\end{tabular}

NUMBER OF REFERENCES

0

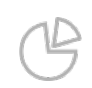

NUMBER OF FIGURES

0

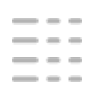

NUMBER OF TABLES

0

(C) The author(s) 2023. This publication is an open access article. 
Behjat Abbasi (Iran), Mohammad Hamed Khan Mohammadi (Iran)

\title{
Effect of strategic management accounting techniques on market share changes in firms in Tehran Stock Exchange market
}

\begin{abstract}
Increasing market share is one of the main challenges of organizations nowadays, in order to guarantee profitability and survival of the organization. Market share index in an indicator of success/failure. The aim of the present study is to investigate the effect of strategic management accounting techniques effect on market share changes in Tehran stock market companies. This is a descriptive research in which information are in collected via secondary data and inspecting financial statements. The purpose is to investigate the relationship between variables of the study and then find their correlation.

Results of the study suggested that market added value, net present value, profitability index and investment return rate are among those accounting strategic techniques that have significant effect on markets market share, but economical added valued doesn't have a significant effect on markets share changes.
\end{abstract}

Keywords: market added value (MAV), economic value added, net present value, profitability index, investment return rate, market share changes.

JEL Classification: G14, G30, M31, M41.

\section{Introduction}

Clearly, working logically and having rational behavior have been in human's nature since the beginning of his life. As a result, productivity and efficiency are among the issues of human research traditionally. On the one hand, human desires and wishes are limitless and, on the other hand, since power of human and his tools and his life time are limited, he has no solution except to make advantage of the available facilities and increase efficiency and productivity as much as possible (Daneshvar, 2006).

Management accounting is a measurement system for gathering financial and operational information that conduct the motivational behavior and create or support the cultural values needed for achieving the strategic goals of the organization. Management accounting wasn't that popular since the twentieth century. Thereafter, it started to develop and nowadays, we can consider it as the newer branch of accounting science. Factors such as increasing privatization, changes in competition patterns, production, companies' structure, technology development speed, global trade show the importance of management accounting in economic firms (Zimmerman, 1997).

In order to improve the performance, using advanced techniques can be useful, because they can help companies to change their direction, speed up or down their growth, make them ready to cope with future threats, and make advantage for their benefits

(c) Behjat Abbasi, Mohammad Hamed Khan Mohammadi, 2016. Behjat Abbasi, Ph.D Student of Accounting, Islamic Azad University, Iran.

Mohammad Hamed Khan Mohammadi, Assistant Professor, Islamic Azad University, Iran. in any situation. Using these main methods, organizations will be able to achieve their goals in difficult situations of economic developments (Daneshvar, 2006).

Companies use their resources in order to be successful in competitive status and improve their situation in future. There are two views for market share: firstly, conspiracy theory on which base, focusing on market share among a few powerful companies, it is possible for them to determine the prices higher than competitive price that leads to a higher normal profit.

Based on the second strategy which is called pragmatic strategy, organizations get market share via increasing company's performance, innovation and economizing.

Regardless of these two strategies, if the goal of the companies is to have higher market share, then, changes in market share will be indictor of their growth opportunities and future performance (Sinayi \& Rashidizad, 2010).

According to the above explanations, the aim of the present study is to investigate the effect of strategic management accounting techniques on market share changes in Tehran stock market companies.

\section{Theoretical principles and history of the research}

Therefore, companies' strategy is highly under the influence of its military roots. According to this point of view, strategy deals with how cope with a competitor (or enemy) and fighting for a territory. Pioneers in this field have suggested to use competitive advantages, fighting for market share and price for successful companies (Kim, W.C. and Mauborgne, R., 2005). 
Margaret (2015) studied the rate of application of management accounting tools by universities' financial managers in the US. Seven tools were investigated in this study of which results showed that factors such as experience, education and having special licenses of management accounting systems are influential in applications of them.

Moeen-al-Din et al. (2014) investigated sensitivity analysis techniques to examine the operational efficiency and management accounting in improvement of the performance of companies with data envelopment analysis in pharmaceutical companies listed on the Tehran Stock Exchange. Results of the models showed that 8 companies (58\% of pharmaceutical ones) have the complete performance (i.e., 1). Also, at the end of the sensitivity analysis of data analysis models, sensitive input and outputs of the studied companies were determined.

Sinayi \& Rashidizad (2013) investigated the correlation of market share gains and the valuation of the company's future growth opportunities. They used multi-regression and simple regression techniques for testing the hypothesis. Results showed that relationship between current and future performance of the company is significantly related to the changes in market share which lasts for 3 years. Also they found out that there is not a significant relationship between criteria of market share changes and growth opportunities.

\section{Method}

Methodologically, this study is a quasi-experimental and post-event investigation in the field of accounting positive research, using real data and can be an applied research because it can be used in the process of using information.

\subsection{Hypothesis:}

1. Net present value of the projects is significantly effective in changes of the market size.

2. Economic added value is significantly effective in changes of the market size.

3. Market added value is significantly effective in changes of the market size.

4. Profitability index is significantly effective in changes of the market size.

5. Return on investment is significantly effective in changes of the market size.

\subsection{Research variables. 2.2.1. Independent} variables.

1. Net present value of the project. Net present value of the project is the difference between current output cash flows of the project minus current input cash flow values expected in future. In order to calculate current value and difference of input/output of the cash flows of the investment, we can use investment cost or investment efficiency rate:

$$
N P V_{i, t}=\sum_{t=1}^{n} \frac{C F_{i, t}}{(1+r)^{n}}-I C O_{i, t}
$$

$N P V_{i, t}$ - net present value of the project;

$C F_{i, t}$ - cash entering flow of company $i$ for period $t$;

$r$ - discount rate or expected return;

$I C O_{i, t}$ - primary output cash flow of company $i$ for time period $t$;

$N$ - expected age of the project.

2. Economic added value. Economic added value is not a measure of strategy economic added value creation, but it is a way to measure the results. A newer version of tools and measures are innovated for evaluation of the performance, of which one is EVA (economic added value). We used Biddle et al. (1997) model for evaluating the EVA:

$$
E V A_{i, t}=\left(r_{i, t}-c_{i, t}\right) \times \text { Capital }_{i, t}
$$

$E V A_{i, t}$ - economic added value of company $i$ in time $t$;

$r_{i, t}$ - performance rate of company $i$ in time $t$;

$c_{i, t}-$ cost rate of investment for company $i$ in time $t$;

capital $_{i, t}$ - capital of company $i$ in time $t$.

3. Market added value. The primary aim of the most companies is to increase their shareholders' wealth. This is achieved via maximizing the difference between stock market value of the company and shareholders' capital. This is called MVA or market value added (Hall \& Brummer, 1999).

MVA = stock market value - shareholders' equity $=$ (number of issued shares) (Stock price disclosed in the report of the Board of Directors) - equity.

4. Return on investment. It is essential for company's survival to earn income, this is calculated via Hall \& Brummer (1999) model as follows:

$$
r_{i, t}=\frac{\operatorname{NOPAT}_{i, t}}{\text { Capital }_{i, t}}
$$

$r_{i, t}-$ rate of investment return rate of company $i$ in time $t$; 
$N O P A T_{i, t}$ - net operational benefit after taxes of company $i$ in time $t$;

Capital $_{i, t}$ - capital of company $i$ in time $t$.

5. Profitability index. Profitability index is a device for evaluating financial success of companies' income related to sales income or to investments. This is called also net margin profit which is obtained via the following equation:

$$
\operatorname{Pro}_{i, t}=\frac{\text { Net } \operatorname{Profit}}{S_{i, t}}
$$

changes in market share $=\left[\frac{\text { sales of company } i \text { in time } t / \text { sales of company } i \text { in time } t-1}{\text { sales of industry } j \text { in time } t / \text { sales of industry } j \text { in time } t-1}\right]$

\section{Experimental results}

3.1. Descriptive statistics. Descriptive statistics are mentioned in Table 1 which shows a general view of the data of the research.

Table 1. Descriptive statistics of the research

\begin{tabular}{|l|c|c|c|c|c|}
\hline \multicolumn{1}{|c|}{ Variables } & Average & Mean & Maximum & Minimum & SD \\
\hline $\begin{array}{l}\text { Net present } \\
\text { value }\end{array}$ & 16723 & 4387 & 2087 & 381 & 192.1 \\
\hline $\begin{array}{l}\text { Economic } \\
\text { added value }\end{array}$ & 20772 & 5532 & 1383 & 2.9 & 21058.21 \\
\hline $\begin{array}{l}\text { Market } \\
\text { added value }\end{array}$ & 22308 & 6204 & 2476 & 2476 & 281 \\
\hline $\begin{array}{l}\text { Investment } \\
\text { return rate }\end{array}$ & 4.561 & 2.066 & 1.083 & 0.91 & 2.106 \\
\hline $\begin{array}{l}\text { Profitability } \\
\text { index }\end{array}$ & 0.453 & 0.000 & 1.000 & 0.000 & 0.498 \\
\hline $\begin{array}{l}\text { Market size } \\
\text { changes }\end{array}$ & 0.04 & 0.000 & 44.80 & 0.000 & 1.47 \\
\hline
\end{tabular}

Descriptive statistics of the net present value show that the average of this variable is 16723 and the mean is 4387. Based on SD which is 19271, it is obvious that dispersion around average for this variable is low.

Descriptive statistics of economic added value show that its average is 20772 and its mean is 4387 . Based on the SD $=21059$, we can conclude that dispersion around average for this variable is low.

Generally, according to the above tables, we can conclude that there is a medium dispersion in all variables obviously shown by SD amounts. Also it is worth to mention that all variables have a relative symmetry according to their average and mean difference.

3.1.1. Testing hypothesis of the research. Testing first hypothesis. The aim of this hypothesis is to investigate if net present value is significantly effective on market size changes or not. The following model was used to test this hypothesis:
Pro $_{i, t}$ - corporate profitability of company $i$ in time $t$;

Net Profit $t_{i, t}$ - net benefit of company $i$ in time $t$; $S_{i, t}-$ sales of company $i$ in time $t$.

2.2.2. Dependent variables. Market size changes (MSC). MSC is the amount of penetration of companies in an industry in the market. The higher MSC, shows the higher level of competitive advantage that can be important in using offensive strategies for the company. In this research, changes in market share is measured via Swirsky (2004) model as follows:

$$
\begin{aligned}
& \operatorname{MSC}_{i, t}=\alpha_{1}+\alpha_{2} \sum_{t=1}^{n} \frac{C F_{i, t}}{(1+r)^{n}}-I C O_{i, t}+\alpha_{3} \text { Size }_{i, t}+ \\
& +\alpha_{4} L Q_{i, t}+\varepsilon_{i, t}
\end{aligned}
$$

Results of the test is presented in the following table:

Table 2. Model results

\begin{tabular}{|l|c|c|c|c|}
\hline \multicolumn{1}{|c|}{ Variable } & Coefficient & $t$-statistic & Significance & VIF \\
\hline Intercept & 0.68 & 2.775 & 0.006 & - \\
\hline $\begin{array}{l}\text { Investment return } \\
\text { rate }\end{array}$ & 0.108 & 1.22 & 0.004 & 4.13 \\
\hline Company size & 0.079 & 1.01 & 0.002 & 1.32 \\
\hline Liquidity & 0.236 & 2.59 & 0.009 & 4.4 \\
\hline $\begin{array}{l}\text { F-statistic } \\
\text { (significance) } \\
\text { Fisher }\end{array}$ & $22.33(0.000)$ & & \\
\hline $\begin{array}{l}\text { Adjusted coefficient } \\
\text { of determination }\end{array}$ & \multicolumn{2}{|c|}{0.715} & & \\
\hline $\begin{array}{l}\text { Durbin-Watson } \\
\text { statistic }\end{array}$ & \multicolumn{2}{|c|}{2.02} & & \\
\hline
\end{tabular}

\subsubsection{Analysis of the results.}

1. F-Fisher statistic. Results of null hypothesis of this test shows there is not any linear relationship between dependent and independent variables. Results of the table with significance level of zero $(<5 \%)$ rejects the null hypothesis with $95 \%$ confidence. In other words, generally, there is a linear relationship between dependent and independent variables of the study and the model is valid enough for results analysis.

2. Adjusted coefficient of determination. Level of determination coefficient is a percentage of dependent variables changes which is explained by the model's independent variables. In this model, determination coefficient is 0.696 .

3. Analysis of the hypothesis results. As mentioned before, the aim of the present study is to investigate the effect of net present value in 
market size changes. Estimations show that variable's error level is 0.009 and variable's error coefficient is 0.236 which shows that there is a positive significant relationship between this variable and market share changes.

As a result, there is no clue to reject this hypothesis and it is confirmed, also there is a significant relationship between market share changes, and market size and equity level.

3.1.3. Testing the second hypothesis. The aim of this hypothesis is to find out if economic added value has any effects on market size changes or not. The following model is used to investigate this hypothesis:

$$
\begin{aligned}
& \operatorname{MSC}_{i, t}=\alpha_{1}+\alpha_{2}\left(r_{i, t}-c_{i, t}\right) \times \text { Capital }_{i, t}+\alpha_{3} \text { Size }_{i, t}+ \\
& +\alpha_{4} L Q_{i, t}+\varepsilon_{i, t}
\end{aligned}
$$

Results of the model are in table below:

Table 3. Model results

\begin{tabular}{|l|c|c|c|c|}
\hline \multicolumn{1}{|c|}{ Variable } & Coefficient & $\begin{array}{c}t \text { - } \\
\text { statistic }\end{array}$ & Significance & VIF \\
\hline Intercept & 0.68 & 2.775 & 0.006 & - \\
\hline Investment return rate & 0.108 & 1.22 & 0.004 & 4.13 \\
\hline Company size & 0.079 & 1.01 & 0.002 & 1.32 \\
\hline Liquidity & 0.236 & 2.59 & 0.009 & 4.4 \\
\hline $\begin{array}{l}\text { F-statistic (significance) } \\
\text { Fisher }\end{array}$ & $22.33(0.000)$ & & \\
\hline $\begin{array}{l}\text { Adjusted coefficient of } \\
\text { determination }\end{array}$ & \multicolumn{2}{|c|}{0.715} & & \\
\hline Durbin-Watson statistic & \multicolumn{2}{|c|}{2.02} & & \\
\hline
\end{tabular}

\subsubsection{Analysis of the results.}

1. F-Fisher statistic. Results of null hypothesis of this test shows there is not any linear relationship between dependent and independent variables. Results of the table with significance level of zero $(<5 \%)$ rejects the null hypothesis with $95 \%$ confidence. In other words, generally, there is a linear relationship between dependent and independent variables of the study and the model is valid enough for results analysis.

2. Adjusted coefficient of determination. Level of determination coefficient is a percentage of dependent variables changes which is explained by the model's independent variables. In this model, determination coefficient is 0.713 .

3. Analysis of the hypothesis results. As mentioned before, the aim of the present study is to investigate the effect of net present value in market size changes. Estimations show that variable's error level is 0.288 and variable's error coefficient is 0.062 .

As a result, there is no clue to confirm this hypothesis and it is rejected.
3.1.5. Testing the third hypothesis. The aim of this hypothesis is to find out if there is any significant effect of market added value on changes of the market size. The following model was used in order to test the third hypothesis:

$$
M S C_{i, t}=\alpha_{1}+\alpha_{2} M V A_{i, t}+\alpha_{3} \text { Size }_{i, t}+\alpha_{4} L Q_{i, t}+\varepsilon_{i, t}
$$

Results of the models are shown in table below:

Table 4. Estimation of the model results

\begin{tabular}{|l|c|c|c|c|}
\hline \multicolumn{1}{|c|}{ Variable } & Coefficient & $\begin{array}{c}t \text { - } \\
\text { statistic }\end{array}$ & Significance & VIF \\
\hline Intercept & 0.729 & 2.14 & 0.001 & - \\
\hline Investment return rate & 0.391 & 2.88 & 0.002 & 1.22 \\
\hline Company size & 0.112 & 0.901 & 0.004 & 1.67 \\
\hline Liquidity & 0.601 & 2.02 & 0.001 & 1.09 \\
\hline $\begin{array}{l}\text { F-statistic (significance) } \\
\text { Fisher }\end{array}$ & $23.75(0.000)$ & & & \\
\hline $\begin{array}{l}\text { Adjusted coefficient of } \\
\text { determination }\end{array}$ & 0.801 & & \\
\hline Durbin-Watson statistic & \multicolumn{2}{|c|}{2.11} & & \\
\hline
\end{tabular}

\subsubsection{Analysis of the results.}

1. F-Fisher statistic. Results of null hypothesis of this test shows there is not any linear relationship between dependent and independent variables. Results of the table with significance level of zero $(<5 \%)$ rejects the null hypothesis with $95 \%$ confidence. In other words, generally, there is a linear relationship between dependent and independent variables of the study and the model is valid enough for results analysis.

2. Adjusted coefficient of determination. Level of determination coefficient is a percentage of dependent variables changes which is explained by the model's independent variables. In this model, determination coefficient is 0.801 .

3. Analysis of the hypothesis results. As mentioned before, the aim of the present study is to find out the effect of market added value in market size changes. Estimations show that variable's error level is 0.391 and variable's error coefficient is 0.002 which shows that there is a positive significant relationship between this variable and market share changes.

As a result, there is no clue to reject this hypothesis and it is confirmed.

3.1.7. Testing the fourth hypothesis. The aim of this hypothesis is to find out if there is any significant effect of profitability index on changes of the market size. The following model was used in order to test the fourth hypothesis:

$$
\begin{aligned}
& \operatorname{MSC}_{i, t}=\alpha_{1}+\alpha_{2} \frac{\text { Net Profit }}{S_{i, t}}+\alpha_{3} \text { Size }_{i, t}+ \\
& +\alpha_{4} L Q_{i, t}+\varepsilon_{i, t} .
\end{aligned}
$$


Results of the models are shown in table below:

Table 5. Estimation of the model results

\begin{tabular}{|l|c|c|c|c|}
\hline \multicolumn{1}{|c|}{ Variable } & Coefficient & $t$-statistic & Significance & VIF \\
\hline Intercept & 0.91 & 2.156 & 0.001 & - \\
\hline $\begin{array}{l}\text { Investment } \\
\text { return rate }\end{array}$ & -0.279 & -1.71 & 0.001 & 4.13 \\
\hline Company size & 0.079 & 1.01 & 0.002 & 1.32 \\
\hline Liquidity & 0.236 & 2.59 & 0.009 & 4.4 \\
\hline $\begin{array}{l}\text { F-statistic } \\
\text { (significance) } \\
\text { Fisher }\end{array}$ & \multicolumn{2}{|c|}{$23.17(0.000)$} & & \\
\hline $\begin{array}{l}\text { Adjusted } \\
\text { coefficient of } \\
\text { determination }\end{array}$ & \multicolumn{2}{|c|}{0.615} & & \\
\hline $\begin{array}{l}\text { Durbin-Watson } \\
\text { statistic }\end{array}$ & \multicolumn{2}{|c|}{2.11} & & \\
\hline
\end{tabular}

\subsubsection{Analysis of the results.}

1. F-Fisher statistic. Results of null hypothesis of this test shows there is not any linear relationship between dependent and independent variables. Results of the table with significance level of zero $(<5 \%)$ rejects the null hypothesis with $95 \%$ confidence. In other words, generally, there is a linear relationship between dependent and independent variables of the study and the model is valid enough for results analysis.

2. Adjusted coefficient of determination. Level of determination coefficient is a percentage of dependent variables changes which is explained by the model's independent variables. In this model, determination coefficient is 0.615 .

3. Analysis of the hypothesis results. As mentioned before, the aim of the present study is to find out the effect of profitability index in market size changes. Estimations show that variable's error level is -0.279 and variable's error coefficient is 0.001 which shows that there is a positive significant relationship between this variable and market share changes.

As a result, there is no clue to reject this hypothesis and it is confirmed. Also, size of the companies and equity level of them have significant effect on market share.

3.1.9. Testing the fifth hypothesis. The aim of this hypothesis is to find out if there is any significant effect of investment return rate on changes of the market size. The following model was used in order to test the fifth hypothesis:

$$
\begin{aligned}
& \operatorname{MSC}_{i, t}=\alpha_{1}+\alpha_{2} \frac{\operatorname{NOPAT}_{i, t}}{\text { Capital }_{i, t}}+\alpha_{3} \text { Size }_{i, t}+ \\
& +\alpha_{4} L Q_{i, t}+\varepsilon_{i, t} .
\end{aligned}
$$

Results of the models are shown in table below:
Table 6. Results of model estimation

\begin{tabular}{|l|c|c|c|c|}
\hline \multicolumn{1}{|c|}{ Variable } & Coefficient & t-statistic & $\begin{array}{c}\text { Significanc } \\
\mathrm{e}\end{array}$ & VIF \\
\hline Intercept & 0.818 & 1.93 & 0.002 & - \\
\hline Investment return rate & 0.282 & 2.16 & 0.009 & 1.22 \\
\hline Company size & 0.112 & 0.901 & 0.004 & 1.67 \\
\hline Liquidity & 0.601 & 2.02 & 0.001 & 1.09 \\
\hline $\begin{array}{l}\text { F-statistic } \\
\text { (significance) Fisher }\end{array}$ & $22.13(0.000)$ & & \\
\hline $\begin{array}{l}\text { Adjusted coefficient of } \\
\text { determination }\end{array}$ & \multicolumn{2}{|c|}{0.667} & & \\
\hline $\begin{array}{l}\text { Durbin-Watson } \\
\text { statistic }\end{array}$ & 2.05 & & \\
\hline
\end{tabular}

\subsubsection{Analysis of the results.}

1. F-Fisher Statistic. We use F-Fisher statistic to determine the significance of the whole model or in other words, to find linear significant relationship between dependent and independent variables. Null hypothesis of the study shows that there isn't any linear relationship between dependent and independent variables. Results of the table with significance level of zero $(<5 \%)$ rejects the null hypothesis with $95 \%$ confidence. In other words, generally, there is a linear relationship between dependent and independent variables of the study and the model is valid enough for results analysis.

2. Adjusted coefficient of determination. Level of determination coefficient is a percentage of dependent variables changes which is explained by the model's independent variables. In this model, determination coefficient is 0.667 .

3. Analysis of the hypothesis result. As mentioned before, the aim of the present study is to find out the effect of investment return rate in market size changes. Estimations show that variable's error level is 0.282 and variable's error coefficient is 0.009 which shows that there is a positive significant relationship between this variable and market share changes.

As a result, there is no clue to reject this hypothesis and it is confirmed.

\section{Conclusion}

Companies use their resources for improving their relative position among their competitors and to promote their situation in future opportunities. In industrial organization studies, market share and its growth are among the most important performance indices for companies. There is also proved to exist a positive relationship between market share and economical profit. If favorable purpose of the companies is to obtain market share, and it is expected to increase it in future, then, changes in market share show the future performance and growth opportunities of the company. Nowadays, 
one of the most important strategies to change market share (especially in services) is to use accounting techniques which have a considerable role in companies' market share. Analysis of the results is as follows:

Hypothesis 1. Net present value of the projects have significant effect on market size changes.

It is worth to mention that if net current value of the projects is increased regarding the income and age of the projects, we can expect that companies' market share trend is positive. Consequently, company's market share in industry is increased relative to other companies and also companies' growth opportunities is increased in order to raise the investments. As a result, public confidence is increased toward the projects of the company and more shareholders will be interested in investing in these organizations.

Hypothesis 2. Economic added value has significant effect on market size changes.

Based on the results of testing the second hypothesis, we can claim that economic added value increase by rising shareholders' wealth. It's also one of the most important criteria of companies' financial performance that is not related significantly with market share changes. One of the advantages of economic added value is providing a unique and shared language in the organization. When economic added value is paid much attention by managers of the company, then, performance of the company will increase because, it gives them responsibility of answering and it can be the only criterion for success. Investigation of managers' performance is very important regarding the paradox between benefits of managers and owners of the business.
Hypothesis 3. Market added value has significant effect on market size.

The primary aim of the most companies is to increase their shareholders' wealth. They also are interested in using their scarce resources to achieve this goal. Shareholders' benefit is maximized via increasing the difference between company's stock market value, and the capital of shareholders. This way, we can expect to increase the market share by increasing added value of the market. The reason is that companies must make enough efforts for gaining more shares from the markets.

Hypothesis 4. Profitability index has a significant effect on market size changes.

We know that with the increase in corporate profitability, market share can also increase. Logically, when companies provide necessary programs and plans for Promotion of their profitability, their aim is to obtain higher market share. This is done by providing high quality services and products and lower prices. This can increase market share for the company and, at the same time, dedicate a distinguished and prominent position to it.

Hypothesis 5. Investment return rate has significant effect on market size.

Factors such as investment return rate, output or return on investment relative to the obtained income equals the original capital. In other words, incomes and costs are always determined with a specified rate in order to increase the investment return rate. Consequently, markets' share changes increase in accordance with investment return rate, because companies should increase their efforts to enhance their products' quality and more investments in projects, etc., then, they can improve their market share.

\section{References}

1. Biddle, G., Bowen, R. \& Wallace J. (1997). Dose (EVA) Beat Earnings? Evidence on Associations with Stock Returns and Firm Values, Journal of Accounting and Economics, 24 (3), pp. 301-336.

2. Daneshvar, Maryam. (2006). Designing and determining a model for evaluation of the efficiency of Dana Insurance using Data cover analysis technique. Master's degree thesis of Industrial management. Tarbiat-eModarres University.

3. Hall, J. \& Brummer, L.M. (1999). The Relationship Between the Market Value of a Company and Internal Performance Measurements. University of Pretoria. Available at: http://papers.ssrn.com/id=141189.

4. Johnson, H.T. and Kaplan, R.S. (1987). Relevance Lost: The Rise and Fall of Management Accounting. Boston: Harvard Business School Press.

5. Kim, W.C. and Mauborgne, R. (2005). Blue ocean strategy: From theory to practice, California Management Review, 47 (3), pp. 105-121.

6. Margaret, J. (2015). The Use of Management Accounting Tools by Chief Financial Officers of Baccalaureate College-General and Masters Colleges and Universities. University of South Dakota.

7. Moeen-al-Din Mahmood, Morovati Sharif Abadi Ali, Fazel Yazdi Ali, Tahari Mehrjerdi Mohamadhossein. (2014). Investigation of productivity and analysis of management accounting operational techniques in improvement of companies' performance using data cover analysis strategy (case study: pharmacological companies in Tehran stock market), Auditing and accounting review quarterly journal, 14, (autumn), pp. 49-65.

8. Namazi Mohamad. (2013). Strategic management accounting, from theory to practice. Vol. 1, 1st print, Tehran: Universities human sciences study and authoring organization. 
9. Sinayi Hasanali, Rashidizad Fateme. (2010). Investigation of the relationship between market share changes with valuation of gains and future growth opportunities of the companies, Auditing and accounting review quarterly journal, 59, pp. 26-31.

10. Sinayi Hasanali, Rashidizad Fateme. (2010). Investigation of the relationship between market share changes with valuation of gains and future growth opportunities of the companies, Auditing and accounting review quarterly journal, 59, pp. 31-46.

11. Swirsky, S. (2004). The implications of market share changes on the market's pricing of earnings. The Florida State University, College of Business.

12. Zimmerman, J. (1997). Managerial Accounting. $1^{\text {st }}$ edition. Irwin Publishing. 